\title{
Shortening procedure : A choice for tuberculous kyphosis correction
}

\author{
Subroto Sapardan, Ismail
}

\begin{abstract}
Abstrak
Kifosis tuberkulosis adalah kelainan tidak stabil yang cenderung bertambah dan menyebabkan banyak masalah. Ada berbagai macam osteotomi yang dilakukan untuk mengkoreksi kifosis yang disebabkan banyak kondisi, namun bukan untuk tuberkulosis. Makalah ini mengajukan shortening procedure untuk mengkoreksi kifosis tuberkulosis. Penelitian praeksperimental dilakukan dengan melibatkan 49 pasien kifosis tuberkulosis yang dioperasi di RSCM dan RS Fatmawati sejak Juni 1996 hingga Juni 2001. Seluruh pasien dievaluasi secara radiografis saat sebelum operasi, setelah operasi, hingga kontrol terakhir (6-36 bulan). Resiko operasi berupa defisit neurologis juga dievaluasi berdasarkan Frankel. Kifosis dikelompokkan dalam tiga grup, yaitu grup A (kifosis $30^{\circ}-59^{\circ}$ ) grup $B\left(60^{\circ}-89^{\circ}\right)$ dan grup $C\left(90^{\circ}-120^{\circ}\right)$. Kifosis pasca operasi rata-rata terkoreksi sebesar $30,82^{\circ}(67,5 \%)$, pada grup A $28^{\circ}(75,49 \%)$, pada grup $B 42,3^{\circ}(62,43 \%)$ dan pada grup C $27^{\circ}(23,36 \%)$. Komplikasi neurologis ditemukan pada 6 pasien (12,2\%); 4 (11,8\%) pada grup A dan 2 (40\%) pada grup C, namun tidak ada perbedaan secara statistik berdasarkan komplikasi yang ditimbulkan antara kedua grup $(p=0,1023)$. Dari hasil diatas disimpulkan bahwa Shortening procedure untuk kifosis tuberculosis memberikan koreksi yang signifikan. Pada kifosis $T B \geq 90^{\circ}$, prosedur ini masih memberikan koreksi yang bermakna secara statistik namun dengan risiko komplikasi neurologis. (Med J Indones 2004; 13: 47-52)
\end{abstract}

\begin{abstract}
Tuberculous kyphosis is an unstable lesion that tends to progress and lead to many problems. Various corrective osteotomies for kyphosis have been described for various conditions, but not for tuberculosis. This articles proposed shortening procedure to correct tuberculous kyphosis. The preexperimental study was conducted in 49 patients with tuberculous kyphosis treated surgically at Cipto Mangunkusumo and Fatmawati hospital since June 1996 till June 2001. All patients were evaluated radiographically in the preoperative period, postoperative period, and at the latest follow-up (6-36 months). Neurological deficit risk of operation was also evaluated by Frankel grading. The kyphosis were classified into three group, group A (kyphosis $\left.30^{\circ}-59^{\circ}\right)$ group B $\left(60^{\circ}-89^{\circ}\right)$ and group $C\left(90^{\circ}-120^{\circ}\right)$. The average postoperative kyphosis correction was $30.82^{\circ}(67.5 \%)$; in group A $28^{\circ}(75.49 \%)$, in group $B 42.3^{\circ}$ $(62.43 \%)$, and in group $C 27^{\circ}(23.36 \%)$. Anova test gave significant difference in persentage of postoperative correction. Paired t-test also gave significance postoperative correction in all groups. Neurological complication was found in 6 patients (12.2\%); 4 (11,8\%) in group A dan 2 (40\%) in group C, and no statistical difference between the two groups concerning this complication ( $p=0.1023$ ). We concluded that shortening procedure for tuberculous kyphosis gave significant correction. In TB-kyphosis $\geq 90^{\circ}$ shortening procedure still gave significant correction although a potential risk of serious neurologic complication. (Med J Indones 2004; 13: 47-52)
\end{abstract}

Keywords: Shortening procedure, tuberculous kyphosis

Tuberculous kyphosis is an unstable lesion that tends to progress at least until there is sound bony fusion anterior and posteriorly. The main problem concerns the evolution of kyphosis. In adults, kyphosis presenting at the end of treatment does not increase in subsequent years. On the other hand, in children, kyphosis becomes more pronounced with growth. ${ }^{1}$ Abnormal posture is associated with increasing

Department of Surgery, Division of Orthopaedics and Traumatology, Faculty of Medicine, University of Indonesia I Dr. Cipto Mangunkusumo Hospital, Jakarta, Indonesia burden on the rest of the spine, causes difficulty in sitting and lying flat, induces pain, and brings a cosmetic problem. Additionally, severe focal deformities can pose a risk to adjacent spinal cord and nerves and impair respiratory function. ${ }^{2}$

Tuberculous kyphosis mostly appears as a short acute kyphosis known as gibbus or kyphus. It is a sagittal plane deformity due to anterior and posterior column discrepancy where the anterior column is shortened due to the tuberculosis incfection. Kyphosis is a change in alignment of a segment of the spine in the sagital plane that increases the posterior convex 
angulation and abnormally increases deformity. There are two clinical types of kyphosis : mobile and rigid.

Kyphosis correction is a procedure of column equalization by anterior lengthening, posterior shortening or combined. Kyphosis has been managed by several surgical procedures. Until now, the following surgical procedures have been practiced by various surgeons: ${ }^{3}$

1. For mobile kyphosis :

Posterior fusion, anterior radical surgery, twostage operation and three stage operation are commonly performed. The two-stage operation consists of anterior release followed by posterior instrumentation and delayed anterior radical surgery.

2. For fixed kyphosis. The rigid deformity can also be corrected by one of the following procedures :

- One-stage operation (posterior closing wedge osteotomy; Galveston: Guven et al, Wu et al) ${ }^{3}$

- Two-stage operation (anterior release, deformity correction and anterior graft, followed by posterior instrumentation $)^{3}$

- Multi-stage operation : nine stage in the Hong Kong Program (preoperative assessment, fitting of the halopelvic distraction apparatus, anterior spinal osteotomy and decompression of the spinal cord, spinal distraction, posterior osteotomy and fusion, further spinal distraction, anterior spine fusion after maximum correction, posterior spine fusion, if not already performed, and postoperative immobilization in halo-pelvic apparatus and in body casts). ${ }^{3,4}$

A two-stage operation has been performed by Moon MS and has given satisfactory result. ${ }^{3}$

Various corrective osteotomies have been described for various conditions. Smith-Petersen et al in 1945 were the first to described a closing-wedge osteotomy in the lumbar spine for the correction of kyphosis in a patient with rheumatoid arthritis. This osteotomy entailed removal of the posterior elements allowing posterior closure with the hinge being the posterior aspect of the vertebral body. Consequently, there is an anterior opening of the disc space. A general rule of thumb for this osteotomy was $1^{\circ}$ of correction for every $1 \mathrm{~mm}$ of bone resected posteriorly. ${ }^{5}$
Since that time, there have been numerous descriptions of different osteotomies with modifications of the original procedure invented to decrease perioperative complications and mortality. La Chapelle advocated anterior discectomy before the posterior closing wedge to allow gentle controlled extension of the spine. ${ }^{6}$ Hehne et al ${ }^{7}$ described their results using a modification of a poly-segemental osteotomy discovered by Puschel and Zielke to allow a more gradual correction over a larger segment of spine. ${ }^{3}$ Thomasen in 1985 and Thiranont and Netrawichien in 1993 reported spinal osteotomies that removed a wedge of bone containing all the posterior elements as well as a portion of the posterior aspect of the vertebral body. ${ }^{8,9}$ Lehmer et al and Gertzbein and Harris in 1992 described their technique of decancellation with removal of the endplate and disc above the apical vertebrae to close a wedge and correct the deformity. ${ }^{10,11}$ Galveston described one-stage operation (posterior closing wedge osteotomy). Essentially, it involved a modified bilateral costotransversectomy approach to the spine, followed by removal of structures in a wedge shape, including the vertebral arch, the disk, and a portion of the centrum. Then the wedge was closed by posterior compression instrumentation, enabling an angular correction of $30^{\circ}$ to $50^{\circ} .^{1}$ This articles proposed shortening procedure to correct tuberculous kyphosis.

\section{METHODS}

The sample population for this preexperimental study consisted of all patients with tuberculous kyphosis treated surgically at a university hospital (Cipto Mangunkusumo and Fatmawati hospital) since June 1996 untill June 2001 with the follow up ranged from 6 to 36 months. Forty nine patients with tuberculous kyphosis have underwent shortening procedure as part of the total treatment approach for tuberculous spondylitis. Shortening procedure must fulfill the following conditions :

- shortening the posterior and middle column (3 column theory) leaving an anterior hinge (resection of spinous process lamina, transverse process, ribs, resection of pedicles, middle column, posterior wall, controlled closure of posterior defect, and cantilever Pedicle Screw Sublaminar Wiring instrumentation).

- the volume of the spinal canal has to remain the same 
- when the length is shortened the circumference must be increased

- decreased spinal canal volume will result in neurological complications

- $\quad$ single staged procedure

The kyphosis were classified into three groups: group A, kyphosis of $30^{\circ}-59^{\circ}$, group B, $60^{\circ}-89^{\circ}$, and group $\mathrm{C}, 90^{\circ}-120^{\circ}$. In the present study there were 34 patients classified as group A, 10 as group B, and 5 as group C.

All patients were evaluated radiographically in the preoperative period, postoperative period, and at the latest follow-up (minimum 6 months). Kyphosis is measured by drawing a line on the upper surface of the first normal vertebra above the lesion and one through the lower surface of the first normal vertebra below the lesion. All radiographs were evaluated by the senior operative spine surgeon. Neurological deficit as a risk of operation was also evaluated by using Frankel grading .

Pre and post correction of kyphosis were stastically analyzed by paired t-test for evaluating improvement in each group. Chi-square or Fisher's exact test (whenever applicable) was applied for evaluating risks of shortening procedure as assessed by Frankel grading. Further, to compare improvement among groups, Anova test was applied.

\section{RESULTS}

Forty nine patients have undergone shortening procedure, of which $26(53.1 \%)$ were male (15 patients at group A, 6 in group B, and 5 in group C), and $23(46.9 \%)$ were female (19 in group A, and 4 in group B). Crosstabulation between groups and sex shows no significant difference (chi-Square test, pvalue $=0.058$ ). The average age was 24.61 years, in group A 26.5 years, group B 22 years, and group C 17 years [Table 1]. Anova test of homogeneity of variances show $\mathrm{p}=0.108$.

Table 1. Subject characterisitic on gender and average of age

\begin{tabular}{ccccccc}
\hline & Group & A & B & C & Total & percent \\
\hline sex & Male & 15 & 6 & 5 & 26 & 53.1 \\
& Female & 19 & 4 & 0 & 23 & 46.9 \\
Mean of age & & 26.5 & 22 & 17 & 24.61 & \\
Range of age & & $12-62$ & $5-36$ & $6-28$ & $5-62$ & \\
\hline
\end{tabular}

Figure 1 shows that the average preoperative kyphosis was $52^{\circ} \pm 27$; in group A $37.62^{\circ} \pm 8.25$, in group B $67.3^{\circ} \pm 6.15$, and in group $C 119.2^{\circ} \pm 10.64$. Anova test showed signicancy difference among these groups. The average postoperative kyphosis was $21.4^{\circ} \pm 30.42$, in group A $9.56^{\circ} \pm 15.43$, in group B $25^{\circ} \pm 22.27$, and in group $\mathrm{C} 92.2^{\circ} \pm 23.19$ [figure 2]. Anova test showed significant different between groups. Figure 3 and 4 represent absolute and percent value of correction, respectively. It is showed that the average correction was $28^{\circ} \pm 15.07(75.49 \% \pm 40.89)$ in group A, $42.3^{\circ} \pm 23.68(62.43 \% \pm 34.66)$ in group B, and $27^{\circ} \pm 14.54(23.36 \% \pm 13.78)$ in group C. Statistical significance was attained for $\%$ correction $(\mathrm{p}=0.021)$. Comparison between pre and post operative kyphosis gave significant different in all groups.

Neurological complication was found in 6 patients $(12.2 \%) ; 4(11,8 \%)$ in group A and $2(40 \%)$ in group $\mathrm{C}$, and no statistical difference was found between the two groups on this complication ( $\mathrm{p}=0.1023)$ [table 2].

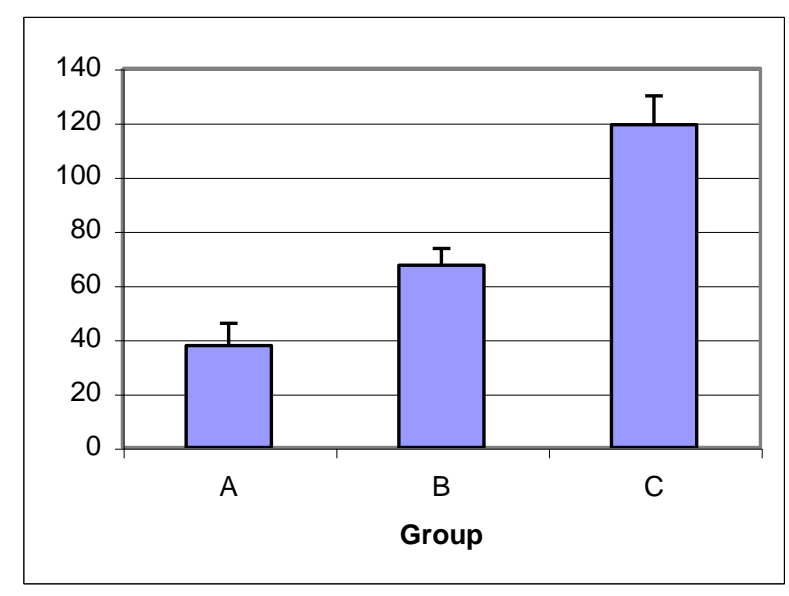

Figure 1. Average pre operative kyphosis

Table 2. Distribution of neurological status of sample after operation

\begin{tabular}{lccc}
\hline \multirow{2}{*}{ Group } & \multicolumn{2}{c}{ Neurological status } & \multirow{2}{*}{ Total } \\
\cline { 2 - 3 } & Decrease & Static/improve & \\
\hline A & $4(11.71 \%)$ & $30(80.29 \%)$ & 34 \\
B & $-(0)$ & $10(23.3 \%)$ & 10 \\
C & $2(40 \%)$ & $3(60 \%)$ & 5 \\
\hline Total & $6(12.2 \%)$ & $43(87.8 \%)$ & 49 \\
\hline
\end{tabular}




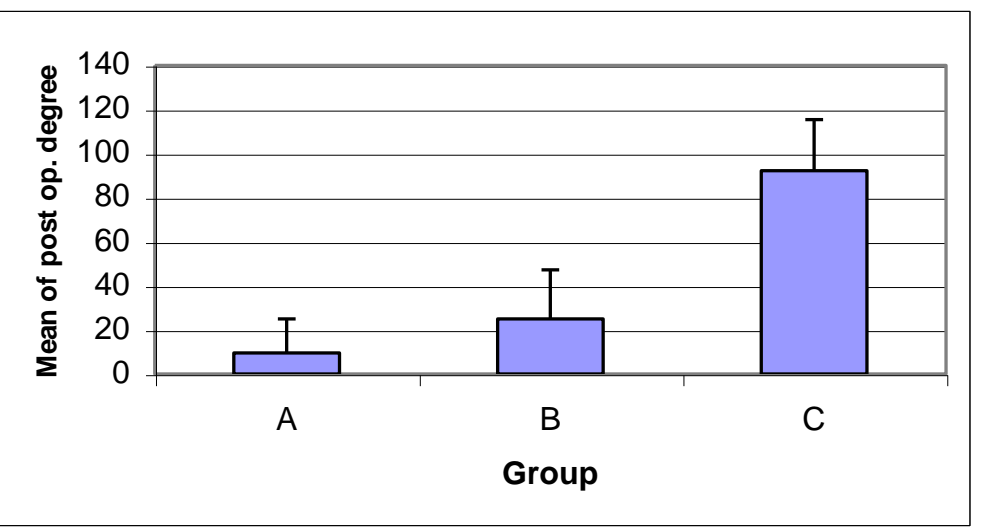

Figure 2. Average of post operative kyphosis

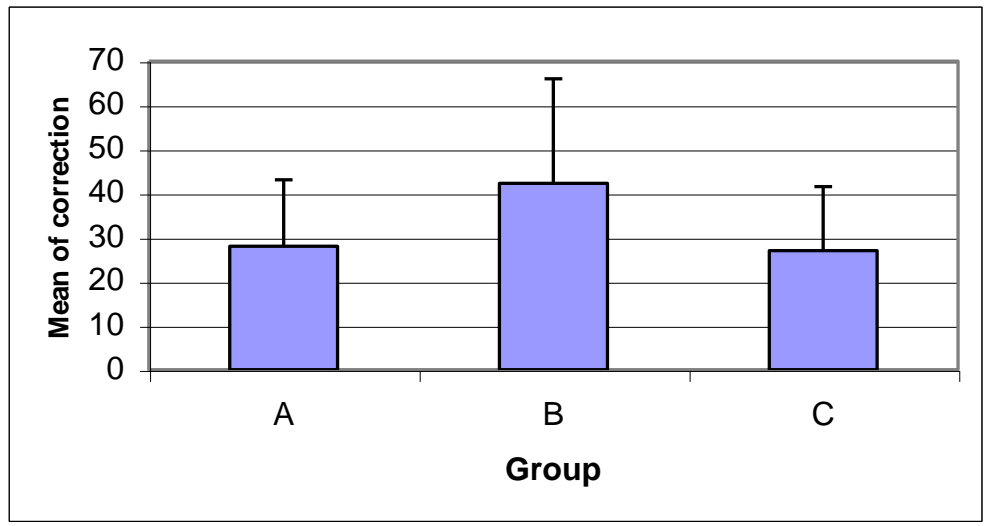

Figure 3. Average of degree of kyphosis correction

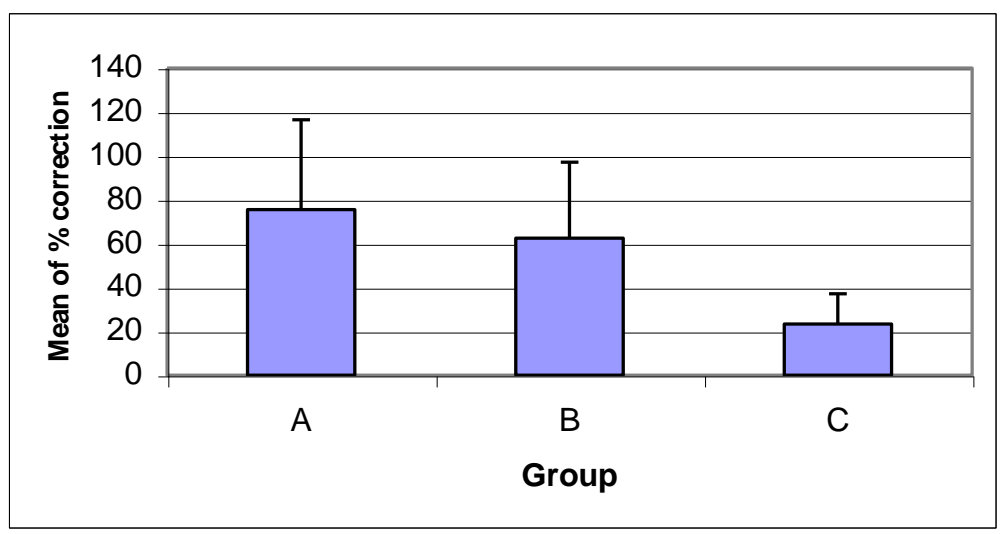

Figure 4. Average of correction percent of kyphosis 


\section{DISCUSSION}

Tuberculosis of the spine can be successfully treated by antituberculous drugs and attention has now turned to the management of residual deformity. In the developing world spinal tuberculosis is the main cause of kyphosis : 15\% of patients treated conservatively have a considerable increase in kyphotic deformity, in which $3 \%$ to $5 \%$ are more than $60^{\circ}$. A severe kyphosis concerns a major cosmetic and psychological disturbance in a growing child, and can result in secondary cardiorespiratory problems and late-onset paraplegia. Correction of an established deformity is both difficult and hazardous with a high rate of complications, even in the experienced hands. ${ }^{12}$ In adults, indication for surgery are infrequent and never imperative. ${ }^{1}$

Vertebral osteotomies have been shown to improve functional outcome in patients with spinal deformity. The indications have been broadened in the last 10 years to include patients with adult scoliosis, failed back syndrome, post-traumatic kyphosis, and postlaminectomy flatback syndrome. ${ }^{13}$ The indications for correcting fixed tuberculosis are unusual, and the practice of this surgery should be limited to a very well equiped institutions. ${ }^{1}$

Surgical correction of fixed tuberculous kyphosis required a complicated program of major surgery (nine stage in the Hong Kong Program). ${ }^{1}$ On the other hand, Moon MS performed a two-stage operation and has come out with satisfactory result. ${ }^{3}$ In our institution, tuberculous kyphosis was a part of tuberculous problem that had to be solved, according to the total treatment approach. Total treatment approach is a protocol for the management of tuberculosis of the spine which offers 10 alternatives of treatment. ${ }^{5}$ This makes easier for the surgeon and the patient to choose the most suitable treatment for all existing problems with the aim of healing infection, with a stable and painless spine. Return of function without unacceptable deformity enables the patients to return to the society, family and occupation. The kyphosis deformity is treated by shortening procedure. ${ }^{14}$

The shortening procedure is performed by removing laminae and facet joints, "precessus transversus", adjacent ribs and middle segment until circumferential decompression of the duramater and cord was achieved. Then the correction is performed by closing the posterior gap with posterior segmental instrumentation. ${ }^{14}$ This alternative was indicated for correction of severe kyphus $60^{\circ}$ to $90^{\circ}$ in a still active or healed disease. The procedure was a very effective one-stage operation. Ahn UM et al reported an average correction of $35^{\circ}$ at each osteotomy, ${ }^{13}$ and $32.4^{\circ}$ in the nine stage Hongkong program. ${ }^{4}$

The shortening procedure had neurological complication in 6 out of 49 patients $(12,2 \%)$. Ahn UM et al reported $12.2 \%$ of minor and $7.3 \%$ of major neurologic complication rate in spinal osteotomy. ${ }^{13}$ Clinically, shortening procedure in group $\mathrm{C}$ has potential serious neurological complication, so we considered to perform it just for decompression and fusion.

Shortening procedure for tuberculous kyphosis gave significant correction. Shortening procedure was still the choice for correction of TB-kyphosis $30^{\circ}-89^{\circ}$ (group A and B), and the neurological complications was $11.8 \%$. TB-kyphosis $\supseteq 90^{\circ}$ (group C) still gave statistically significant correction and potential risk serious neurologic complication, but not statistically different to group A.

\section{Acknowledgement}

The authors would like to thank Dr. Adang Bachtiar, $\mathrm{MPH}, \mathrm{PhD}$ for his substantial support in statistical analysis.

\section{REFERENCES}

1. Ouahes M, Martini M. Tuberculosis of the spine. In Martini M, Ed. Tuberculosis of the bones and joints. Berlin : Springer-Verlag, 1988;157-200.

2. Li F, Sagi Hc, Liu B, Yuan HA. Comparative evaluation of single-level closing wedge vertebral osteotomies for the correction of fixed kyphotic deformity of the lumbar spine a cadaveric study. Spine 2001;26: 2385-91.

3. Moon MS. Tuberculosis of the spine controversies and a new challenge. Spine 1997;22:1791-97.

4. Yau MC, Hsu LCS, O’Brien JP, Hodgdon AR. Tuberculous kyphosis correction with spinal osteotomy, halo-pelvic distraction and anterior and posterior fusion. $\mathbf{J}$ Bone J Surg [Am] 1974; 56-A, 7 : 1419-34.

5. Smith-Peterson M, Larson CB, Aufranc OE. Osteotomy of the spine for correction of flexion deformity in rheumathoid arthritis. J Bone Joint Surg Am 1945;27 :1.

6. LaChapelle EH. Osteotomy of the lumbar spine for correction of kyphosis in a case of ankylosing spondyloarthritis. J Bone J Surg [Am] 1946; 28:851-8. 
7. Hehne HJ, Zielke K, Bohm H. Polysegmental lumbar osteotomies and transpedicular fixation for correction of long curved kyphotic deformities in ankylosing spondylitis: report on 177 cases. Clin Orthop 1990;258:49-55.

8. Thomasen E. Vertebral osteotomy for correction of kyphosis in ankylosing spondylitis. Clin Orthop 1985;194:142-52.

9. Thiranont N, Netrawichien P. Transpedicular decancellation closed wedge vertebral osteotomy for treatment of fixed flexion deformity of spine in ankylosing spondylitis. Spine 1993;18:2517-22.

10. Lehmer SM, Keppler L, Biscup RS, et al. Posterior transvertebral osteotomy for adult thorcalumbar kyposis. Spine 1994;19: 2060-7.
11. Gertzbein SD, Harris MB. Wedge osteotomy for the correction of posttraumatic kyphosis : a new technique and report of three cases. Spine 1992;17:374-9.

12. Rajasekaran S. the natural history of post-tubercular kyphosis in children radiological signs which predicts late increase in deformity. J Bone J Surg [Br] 2001; vol 83B,7 : 954-62.

13. Ahn UM, Ahn NU, Buchowski JM, Kebaish KM, Lee JH, et al. Functional outcome and radiographic correction after spinal osteotomy. Spine 2002;27:1303-11.

14. Sapardan S. Tb spine : the rationale for surgical treatment. Paper presented in APOA, Malaysia, 7 August, 2001. 